In Submarine Mass Movements and Their Consequences - 6th International SymposiumAdvances in Natural and Technological Hazards Research Volume 37, pp 141-150

2014

Eds Sebastian Krastel, Jan-Hinrich Behrmann, David Völker, Michael Stipp, Christian Berndt, Roger Urgeles, Jason Chaytor, Katrin Huhn, Michael Strasser, Carl Bonnevie Harbitz, Springer ISBN 9783319009711 http://dx.doi.org/10.1007/978-3-319-00972-8 13 c) 2014, Springer International

\title{
Chapter 13. Fluid Seepage in Relation to Seabed Deformation on the Central Nile Deep-Sea Fan, Part 2: Evidence from Multibeam and Sidescan Imagery
}

\author{
Daniel Praeg ${ }^{1, *}$, João Marcelo Ketzer ${ }^{2}$, Adolpho Herbert Augustin ${ }^{2}$, Sébastien Migeon $^{3}$, \\ Silvia Ceramicola ${ }^{1}$, Alexandre Dano ${ }^{3}$, Emmanuelle Ducassou ${ }^{5}$, Stéphanie Dupré ${ }^{6}$, Jean Mascle ${ }^{4}$, \\ Luiz Frederico Rodrigues ${ }^{2}$
}

\footnotetext{
1 OGS (Istituto Nazionale di Oceanografia e di Geofisica Sperimentale), Borgo Grotta Gigante 42c, 34010, Trieste, Italy

${ }^{2}$ Center of Excellence in Research and Innovation in Petroleum, Mineral Resources and Carbon Storage (CEPAC), Pontifical University of Rio Grande do Sul (PUCRS), Av. Ipiranga 6681, Prédio 96J, CEP 90619-900, Porto Alegre, RS, Brazil

${ }^{3}$ Géoazur, UMR7329, UNS-UPMC-CNRS-OCA, Rue Albert Einstein, 06560, Valbonne, France

${ }^{4}$ Géoazur, UMR7329, UNS-UPMC-CNRS-OCA, Porte de la Darse, Villefranche-sur-Mer, France

${ }^{5}$ Université Bordeaux 1, UMR5805 EPOC, Avenue des facultés, 33405, Talence, France

${ }^{6}$ IFREMER, Technopôle Brest-Iroise, 29280, Plouzané, France

*: Corresponding author : Daniel Praeg, dpraeg@ogs.trieste.it
}

\begin{abstract}
:
On the central Nile deep-sea fan, stratified sediments overlying mass-transport deposits (MTDs) are deformed into slope-parallel seabed undulations associated with fluid seepage. The western part of this system, in water depths of 1,950-2,250 $\mathrm{m}$, is examined using multi-frequency data from hullmounted and deep-towed swath/profiling systems. Sub-bottom profiles show sub-vertical fluid pipes that terminate both at and below seabed, and gas signatures along fault planes bounding the undulations. Fluid seepage is recorded by high- to intermediate-backscatter patches (HBPs, IBPs) that differ in appearance on multibeam imagery $(30 \mathrm{kHz}, \leq 3 \mathrm{~m}$ penetration) and sidescan swaths (170/190 $\mathrm{kHz},<0.1 \mathrm{~m}$ penetration). Comparison of the two suggests a distinction of (a) buried carbonates ( $0.1-$ $3 \mathrm{~m})$, (b) broad near-seabed $(<0.1 \mathrm{~m})$ carbonate pavements elongate along the undulations, (c) subcircular areas of seabed seepage up to $300 \mathrm{~m}$ across. Four of the latter have narrower gas flares at their edges rising 400-800 m above seabed. These results are consistent with an evolving system of narrow fluid conduits that support the growth and burial of carbonate pavements, shifting over millennial timescales along linear zones parallel to fault planes rooted in MTDs. Sediment deformation above MTDs is inferred to provide pathways for fluid escape, but migration of gas-rich fluids from depth is likely to have facilitated slope destabilisation.
\end{abstract}




\subsection{Introduction}

Fluids play a key role in submarine slope stability (Sultan et al. 2004), but the relation of sediment failure to fluid migration and seepage remains poorly understood (Locat and Lee 2002). Seabed seepage may occur in association with different types of slope destabilisation (e.g. Lastras et al. 2004; Loncke et al. 2004; Paull et al. 2008), but it is unclear whether as consequence or cause. The central Nile Deep-Sea Fan (NDSF) provides an interesting example: slope-parallel seabed undulations, composed of stratified sediments up to $100 \mathrm{~ms}$ thick above mass-transport deposits (MTDs), are interpreted to record gravity-driven deformation in association with fluid seepage (Loncke et al. 2002, 2004; Bayon et al. 2009b; Migeon et al. 2013). Sub-bottom profiles indicate internal structures consistent with creeping and/or gliding, while fluid seepage is recorded by multibeam backscatter anomalies up to $400 \mathrm{~m}$ across corresponding to depressions or low mounds (Loncke et al. 2002, 2004). Submersible observations show backscatter anomalies to correspond to exposed carbonate pavements and suggest a model in which deformation of sediment above a decollement at the top of the MTDs has created pathways for fluid migration along the troughs of the undulations (Bayon et al. 2009b).

New high-resolution information was acquired across the central NDSF during the 2011 APINIL campaign (Fig. 1), using hull-mounted and deep-towed swath/profiling systems. The results provide evidence that whereas undulations in the east correspond to deformation structures that are being progressively transformed into sediment waves, in the west younger undulations record ongoing deformation and fluid venting, above an MTD dated to c.73ka (Migeon et al. 2013, Dano et al., 2013). Here we focus on part of the western area (Fig. 1) where coincident data were acquired using multibeam, sidescan and sub-bottom systems, allow a multi-frequency analysis of seabed features of fluid seepage in relation to sub-bottom evidence of fluid migration through the deformation structures.

\subsection{Methods}

Multibeam data were acquired using a hull-mounted Simrad EM302 (27-33kHz), yielding DTMs with cell-sizes of $25 \mathrm{~m}$ (bathymetry) and $10 \mathrm{~m}$ (backscatter). Water column data were acquired along selected swaths and processed using Fledermaus Midwater. Sub-bottom profiles were acquired with a hull-mounted Chirp system $(1.8-5.3 \mathrm{kHz})$. Sidescan sonar imagery and $2-5 \mathrm{kHz}$ profiles were acquired using the deep-towed SAR (Système Acoustique Remorqué) developed by Ifremer, towed $80-100 \mathrm{~m}$ above seabed. The sidescan sonar $(170 / 190 \mathrm{kHz})$ insonified a swath up to $1100 \mathrm{~m}$ wide with a theoretical resolution up to $25 \mathrm{~cm}$ across-track and $1 \mathrm{~m}$ along-track, here gridded to $1.5 \mathrm{~m}$ pixels. SAR water column data were visualised using Sonarscope software (see Dano et al. 2013). In comparing seabed imagery, penetration of marine muds by sonar systems decreases with frequency and offset (Mitchell 1993), such that a deep-towed $170 / 190 \mathrm{kHz}$ sidescan will penetrate $\leq 10 \mathrm{~cm}$, while a hullmounted $30 \mathrm{kHz}$ multibeam may penetrate up to $3 \mathrm{~m}$ (as demonstrated by Migeon et al. 2010). 


\subsubsection{Faults and fluid indicators on sub-bottom profiles}

Sub-bottom profiles across undulations in the study area show that stratified sediments up to $70 \mathrm{~ms}$ thick, and the top of the underlying MTD, are both offset by faults to form rotated sediment blocks (Fig. 2b); in places rollover anticlines suggest listric faults (Fig. 2c). Most faults lie beneath the downslope faces of undulations (Fig. 2; see also Fig. 2 in Dano et al. 2013), although a few dip upslope (Fig. 2b).

The profiles also reveal two kinds of near-seabed amplitude anomaly within the stratified sediments, incoherent acoustic facies (IAF) and pipes (Fig. 2). IAF are diffuse zones of amplitude enhancement, typical of free gas on high-frequency profiles; such an interpretation is supported by their coincidence with hydro-acoustic flares in the water column at two sites, both above faults (Fig. 2a,b). Pipes are common across the study area, as sub-vertical to inclined amplitude anomalies up to $15 \mathrm{~m}$ wide, most not coincident with faults (Fig. 2b,c); some terminate a few meters below seabed (Fig. 2c-inset), and not all of those that reach seabed coincide with backscatter anomalies (cf. Fig. 3). These observations are coherent with interpretations of pipes as products of past or ongoing fluid migration, fracturing and cementation (Andresen 2012).

\subsubsection{Seabed backscatter anomalies at differing frequencies}

Multibeam and sidescan sonar imagery across the same area of seabed undulations are shown in Fig. 3. The 10m multibeam DTM shows many high-backscatter patches (HBPs), sub-circular to elongate, up to $400 \mathrm{~m}$ across, with no obvious pattern in their distribution or orientation. Smaller and/or intermediate-backscatter patches are also observed, but are difficult to distinguish from noise (Fig. 3). The larger HBPs are comparable to those previously observed on the central NDSF using a $50 \mathrm{~m}$ DTM based on $12-30 \mathrm{kHz}$ multibeam imagery (Loncke et al. 2004; Bayon et al. 2009b). Comparison to the sidescan sonar swath shows the multibeam HBPs to correspond to three possible signatures: 1) areas of 'normal' backscatter (i.e. no anomalies); 2) patches of variable but intermediate backscatter (IBPs), elongate up to $850 \mathrm{~m}$ along the seabed undulations (see Dano et al. 2013), many of which overlap with the multibeam anomalies but are generally of greater extent; 3) sub-circular high-backscatter patches (HBPs) up to $300 \mathrm{~m}$ wide that coincide with, or lie within, the multibeam HBPs. Conversely, a comparison of the broad sidescan IBPs with multibeam backscatter suggests that many have some expression as intermediate multibeam amplitudes that are difficult to delineate.

These differences can be explained by differing penetration of the $30 \mathrm{kHz}$ multibeam and $170 / 190 \mathrm{kHz}$ sidescan sonar systems: multibeam backscatter integrates acoustic anomalies to depths of several meters, while the sidescan only sees features within $0.1 \mathrm{~m}$ of seabed (at higher resolution). Thus we infer that some multibeam HBPs are buried to depths of $0.1-3 \mathrm{~m}$, whereas sidescan IBPs vs HPBs distinguish different kinds of feature at or near seabed. 
Assuming backscatter anomalies to be caused by authigenic carbonates, sidescan amplitudes may be enhanced by bioactivity and micro-relief in areas of gas venting, and/or reduced by a thin sediment veneer (cf. Dupré et al. 2010). In support of burial, patches of intermediate- (variable) and high-backscatter have been observed on $75 \mathrm{kHz}$ sidescan imagery (penetration $<1 \mathrm{~m}$ ) on the central Nile fan upslope of the seabed undulations, and submersible transects only encountered exposed carbonates, and bioactivity, across the HBPs (Bayon et al. 2009b, Fig. 4). One question is why the elongate IPBs, if within $0.1 \mathrm{~m}$ of seabed, are of greater extent than multibeam HBPs (Fig. 3)? This could be explained if multibeam backscatter strength depends on the total thickness of reflective material within the upper $<3 \mathrm{~m}$ sub-seabed; then parts of large sidescan IBPs could correspond to thin nearseabed sheets, within which occur smaller areas of thicker material (e.g. carbonates).

\subsubsection{Water column gas flares}

Multibeam water column data allow the identification and positioning of four hydro-acoustic flares, rising 400-800m above seabed to water depths of 1400-1800m (Figs 3,4). The base of each flare is c. $100 \mathrm{~m}$ wide and lies at the edge of a multibeam HBP (Fig. 3); three lie within the SAR swath and are seen to coincide with the edges of sidescan HBPs (Fig. 4). Two of the flares ( $<250 \mathrm{~m}$ from the swath centre) were visualised on higher resolution sidescan water colum data (Fig. 2a), which shows each to correspond to a pair of narrower flares $\leq 10 \mathrm{~m}$ wide and c.60m apart (Fig. 4d,e; see Dano et al. 2013). Thus gas is rising from relatively small $(\leq 10 \mathrm{~m})$ sites at the edges of larger backscatter anomalies (corresponding to HPBs on both sidescan and multibeam imagery).

\subsection{Discussion}

\subsubsection{Growth and burial of carbonate pavements}

Backscatter anomalies on the central NDSF have been correlated to seabed exposures of authigenic carbonates, formed in response to the upward flow of methane-rich fluids (Bayon et al. 2009a, b). Our comparison of multibeam and sidescan backscatter signatures suggests instead that multibeam HPBs indicate the presence of carbonates within the upper few meters of sediment, not necessarily exposed at seabed. Moreover, sidescan imagery indicate a near-seabed $(<0.1 \mathrm{~m})$ distinction between sub-circular high-backscatter patches (HBPs), several associated with gas flares at their edges, and larger intermediatebackscatter patches (IBPs) inferred to correspond to elongate carbonate pavements resulting from past seepage (see Dano et al. 2013). Interestingly, the sidescan IBPs overlap with but are of greater extent than multibeam HBPs, which can be explained if the IBPs include relatively thin near-seabed carbonate sheets. Water column data show gas is currently venting from only a few sites at the edges of HPBs, via flares $\leq 10 \mathrm{~m}$ wide on sidescan imagery, comparable to the widths of fluid pipes observed on sub-bottom profiles (Fig. 2). 
These results are consistent with changes in fluid seepage over time to drive the growth of carbonate pavements and their progressive burial within near-seabed sediments. As suggested by Dupré et al. (2010), blockage of upward flow by carbonate growth provides a mechanism to laterally displace seepage sites and allow the formation over time of broad sheets. Dating of carbonate crusts elsewhere on the central NDSF indicates downward growth (Bayon et al. 2009a), and the diversion of flow beneath carbonate pavements is one means to allow the lateral growth of thin sheets. In addition, our observations of sub-vertical pipes, some of which do not reach seabed (Fig. 2b), show that individual fluid conduits may be abandoned. We infer an evolving system of sub-vertical conduits, feeding sites of seepage and the lateral growth of broad carbonate sheets, both of which can cease to be active and become progressively buried.

The timescales over which carbonates form and are buried may be estimated from sedimentation rates. Two cores from the central NDSF near the study area indicate rates of $2 \mathrm{~cm} / \mathrm{ka}$ over the last $5 \mathrm{ka}, 10-16 \mathrm{~cm} / \mathrm{ka}$ from $5-15 \mathrm{ka}$ and $2-11 \mathrm{~cm} / \mathrm{ka}$ from $15-70 \mathrm{ka}$ (Ducassou et al. 2009). Thus carbonates observed with sidescan imagery, assuming they are within $10 \mathrm{~cm}$ of seabed, must have formed during the last $5 \mathrm{ka}$, while features within the upper $2-3 \mathrm{~m}$ of sediment may date back at least to the last glacial maximum. This suggests changes in sites of seepage over millennial timescales to allow the growth of elongate carbonate pavements. This estimate is consistent with a c.8ka age obtained by U/Th dating of carbonate pavements on the central Nile fan to the east (Fig. 1; Bayon et al. 2009a), in an area where buried pavements are inferred to have been exposed by seabed erosion by turbulent flows (Migeon et al. 2013, Dano et al. 2013).

\subsubsection{Fluid migration along fault planes}

We infer that sites of fluid flow and seepage shift over relatively short timescales to allow the growth of carbonate pavements along linear zones parallel to the seabed undulations. The formation of pavements appears to be favoured along the downslope-facing flanks of the undulations (see Dano et al. 2013), which correspond to fault planes bounding rotated sediment blocks (Fig. 2). This suggests the faults are acting as preferential pathways for fluid migration and influencing the localisation of fluid conduits. The distribution of pipes clearly shows that fluid conduits are not restricted to the faults (Fig. 2), nonetheless the observation of elongate carbonate pavements on sidescan imagery suggests that over time fluid seepage shifts along zones parallel to the fault planes.

This finding concurs with the model of Bayon et al. (2009b), who suggested that sediment deformation controls fluid escape on the central NDSF. However, their model envisages fluid flow along a planar boundary at the top of the MTDs, serving as a decollement for deformation driven by dewatering. In our study area, faults are observed to offset the top of the MTD (Fig. 2), and so must extend downward into it (see also Migeon et al., Dano et al., 2013). Given that fluid seepage on the NDSF is not confined to the area of seabed undulations (e.g. Loncke et al. 2004), it seems unlikely that gas-rich fluids are derived only from the MTDs and the $<70 \mathrm{~ms}$ of sediment overlying them. We suggest that gas-rich fluids are derived from greater depths, and pass through the MTDs to reach seabed, exploiting pathways created by sediment deformation. If fluid migration pathways are indeed a 
consequence of deformation, the question remains whether fluids are contributing to the deformation? One hypothesis is that rising gas-rich fluids pass through the MTDs to generate overpressures below the base of the overlying fine-grained sediment cover, such that the upper part of the MTD acts as a decollement to superficial failure (see Migeon et al. 2013). Another possibility is that the MTDs instead act as barriers to fluid flow so that, following their emplacement, gas accumulation at their base leads to overpressures that drive or enhance post-failure deformation, ultimately impacting on the sediment cover to allow fluid escape.

\subsection{Conclusions}

A multi-frequency comparison of seabed backscatter signatures on the central Nile fan using multibeam and sidescan sonars indicates three types of anomaly linked to fluid seepage: buried carbonates $(0.1-3 \mathrm{~m})$, elongate near-seabed $(<0.1 \mathrm{~m})$ pavements produced by past fluid seepage and smaller areas of ongoing seabed seepage. Sites of seepage through vertical conduits are inferred to have shifted over timescales of millennia to build up broader carbonate sheets, preferentially along linear zones above fault planes bounding rotated sediment blocks that root in underlying MTDs. Sediment deformation has thus provided pathways for fluid escape to seabed above the MTDs, but upward fluid migration beneath the MTDs is likely to have driven or enhanced sediment destabilisation.

\section{Acknowledgments}

The authors thank the captain and crew of the $r / v$ Le Suroît and their colleagues at sea and ashore who supported the APINIL campaign. This work was funded by CNRS-INSU and the French program Action Marges. We thank John Woodside (Amsterdam) and Fernando Freire (Petrobras, Rio de Janeiro) for useful reviews of the manuscript.

\section{References}

Andresen KJ (2012) Fluid flow features in hydrocarbon plumbing systems: what do they tell us about the basin evolution? Mar Geol 332-334:89-108.

Bayon G, Henderson GM, Bohn M (2009a) U-Th stratigraphy of a cold seep carbonate crust. Chem Geol 260:47-56.

Bayon G, Loncke L, Dupré S, Caprais J-C, Ducassou E, Duperron S, Etoubleau J, Foucher J-P, Fouquet Y, Gontharet S, Henderson GM, Huguen C, Klaucke I, Mascle J, Migeon S, Ondréas H, Pierre C, Sibuet M, Stadnitskaia A, Woodside J (2009b) Multi-disciplinary investigation of fluid seepage on an unstable margin: The case of the Centre Nile deep sea fan. Mar Geol 26:92-104

Dano A, Praeg D, Migeon S, Augustin J-M, Ceramicola S, Ketzer JM, Augustin AH, Ducassou E, Mascle J (2013) Fluid seepage in relation to seafloor deformation on the central Nile DeepSea Fan, part 1: evidence from side-scan sonar data. In: Krastel S Behrmann J-H, o I er Stipp M, Berndt C, Urgeles R, Chaytor J, Huhn K, Strasser M, Harbitz CB (eds) Submarine 
mass movements and their consequences, 6th international symposium. Springer, Switzerland/Heidelberg/New York/Dordrecht/London, pp 129-139.

Ducassou E, Migeon S, Mulder T, Murat A, Capotondi L, Bernasconi SM, Mascle J (2009) Evolution of the Nile deep-sea turbidite system during the Late Quaternary : influence of climate change on fan sedimentation. Sedimentology 56:2061-2090.

Dupré S, Woodside J. Klaucke I, Mascle J, Foucher J-P (2010) Widespread active seepage activity on the Nile deep Sea Fan (offshore Egypt) revealed by high-definition geophysical imagery. Mar Geol 275:1-19.

Lastras G, Canals M, Urgeles R, Hughes-Clarke JE, Acosta J (2004) Shallow slides and pockmarks swarms in the Eivissa Channel, western Mediterranean Sea. Sedimentology 51:837-850.

Locat J, Lee HJ (2002) Submarine landslides: advances and challenges. Can Geotech J 39:193-212.

Loncke L, Gaullier V, Bellaiche G, Mascle J (2002) Recent depositional patterns of the Nile deep-sea fan from echo-character mapping. AAPG Bulletin 86 (7):1165-1186.

Loncke L, Mascle J, Fanil Scientific Parties (2004) Mud volcanoes, gas chimney, pockmarks and mounds in the Nile deep-sea fan (Eastern Mediterranean): geophysical evidences. Mar Pet Geol 21:669-689.

Migeon S, Ceramicola S, Praeg D, Ducassou E, Dano A, Ketzer JM, Mascle J (2013) Postfailure processes on the continental slope of the Central Nile Deep-Sea Fan: interactions between fluid seepage, creeping and sediment wave construction. In: Krastel S, Behrmann J-H, Vo Iker D, Stipp M, Berndt C, Urgeles R, Chaytor J, Huhn K, Strasser M, Harbitz CB (eds) Submarine mass movements and their consequences, 6th international symposium. Springer, Switzerland/Heidelberg/New York/Dordrecht/London, pp 117-127.

Migeon S, Ducassou E, Le Gonidec Y, Rouillard P, Mascle J, Revel-Rolland M (2010) Lobe construction and sand/mud segregation by turbidity currents and debris flows on the western Nile deep-sea fan (Eastern Mediterranean). Sed Geol 133(3-4):265-293.

Mitchell NC (1993) A model for attenuation of backscatter due to sediment accumulations and its application to determine sediment thicknesses with GLORIA sidescan sonar. J Geoph Res 98(B12):22,477-22,493.

Paull CK, Ussler W, Holbrook WS, Hill TM, Keaten R, Mienert J, Haflidason H, Johnson JE, Winters WJ, Lorenson TD (2008) Origin of pockmarks and chimney structures on the flanks of the Storegga Slide, offshore Norway. Geo-Mar Lett 28:43-51.

Sultan N, Cochonat P, Canals M, Cattaneo A, Dennielou B, Haflidason H, Laberg JS, Long D, Mienert J, Trincardi F, Urgeles R, Vorren TO, Wilson C (2004) Triggering mechanisms of slope instability processes and sediment failures on continental margins: a geotechnical approach. Mar Geol 213:291-321. 


\section{Figures}

Fig. 13.1 Bathymetric map of central NDSF showing study area location. Black parallel lines denote SAR sidescan transects. White continuous lines are the crests of seabed undulations; red dots are multibeam high-backscatter patches. The red square locates an area of submersible investigations of carbonate pavements (Bayon et al. 2009b).

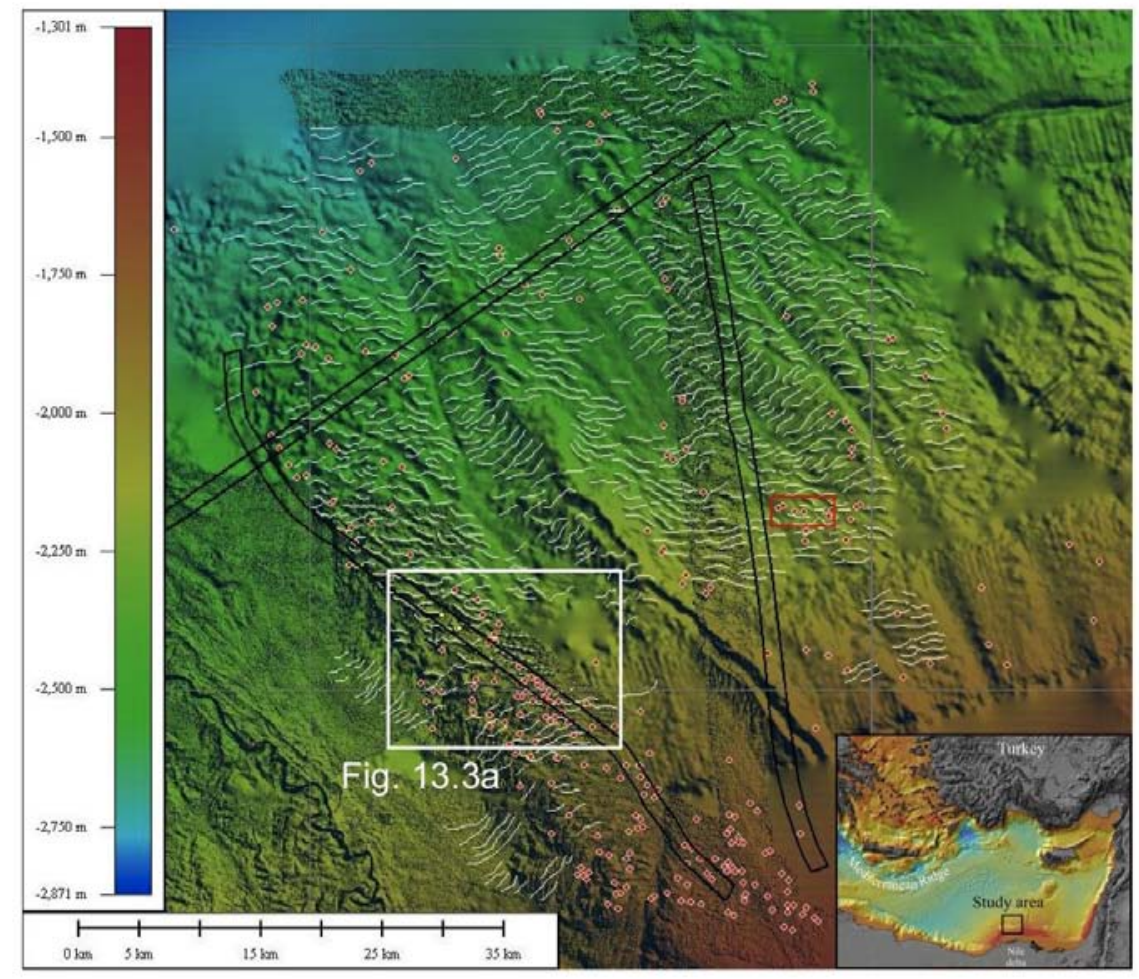


Fig. 13.2 - Sub-bottom profiles across seabed undulations (locations in Fig. 3): a) SAR 2-5 $\mathrm{kHz}$ profile showing incoherent acoustic facies (IAF), coincident with gas flares observed on $170 / 190 \mathrm{kHz}$ sidescan data (in colour, water column swaths projected into vertical plane see Dano et al. 2013); b) hull-mounted Chirp 1.8-3.5 kHz profile subparallel with above (see Fig. 13.3a,d) showing fault-block rotations, sub-vertical fluid pipes and IAF; c) hull-mounted Chirp profile across an area lacking seabed backscatter anomalies, showing sub-vertical fluid pipes, two of which do not reach seabed, and rollover anticlines consistent with listric faults.
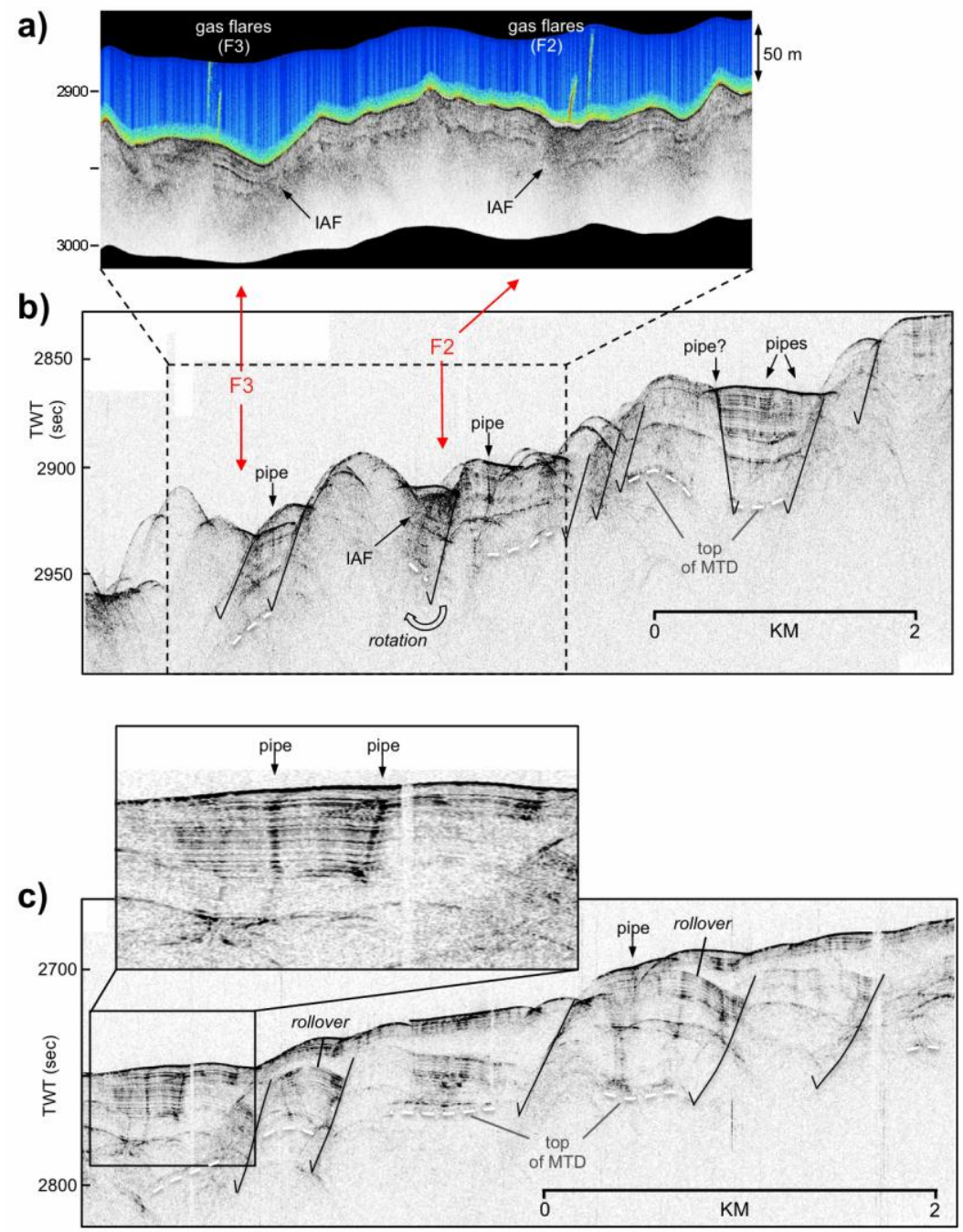
Fig. 13.3 - Comparison of seabed imagery from multibeam and sidescan sonars (location in Fig. 1): a) EM302 multibeam backscatter (10m DTM) showing high-backscatter patches and the locations of four gas flares (F1-4); b,c) comparison of multibeam backscatter anomalies (left) with high- and intermediate-backscatter patches (HBPs, IPBs) seen on SAR sidescan imagery (right); d) comparison of multibeam and SAR backscatter anomalies as in b).

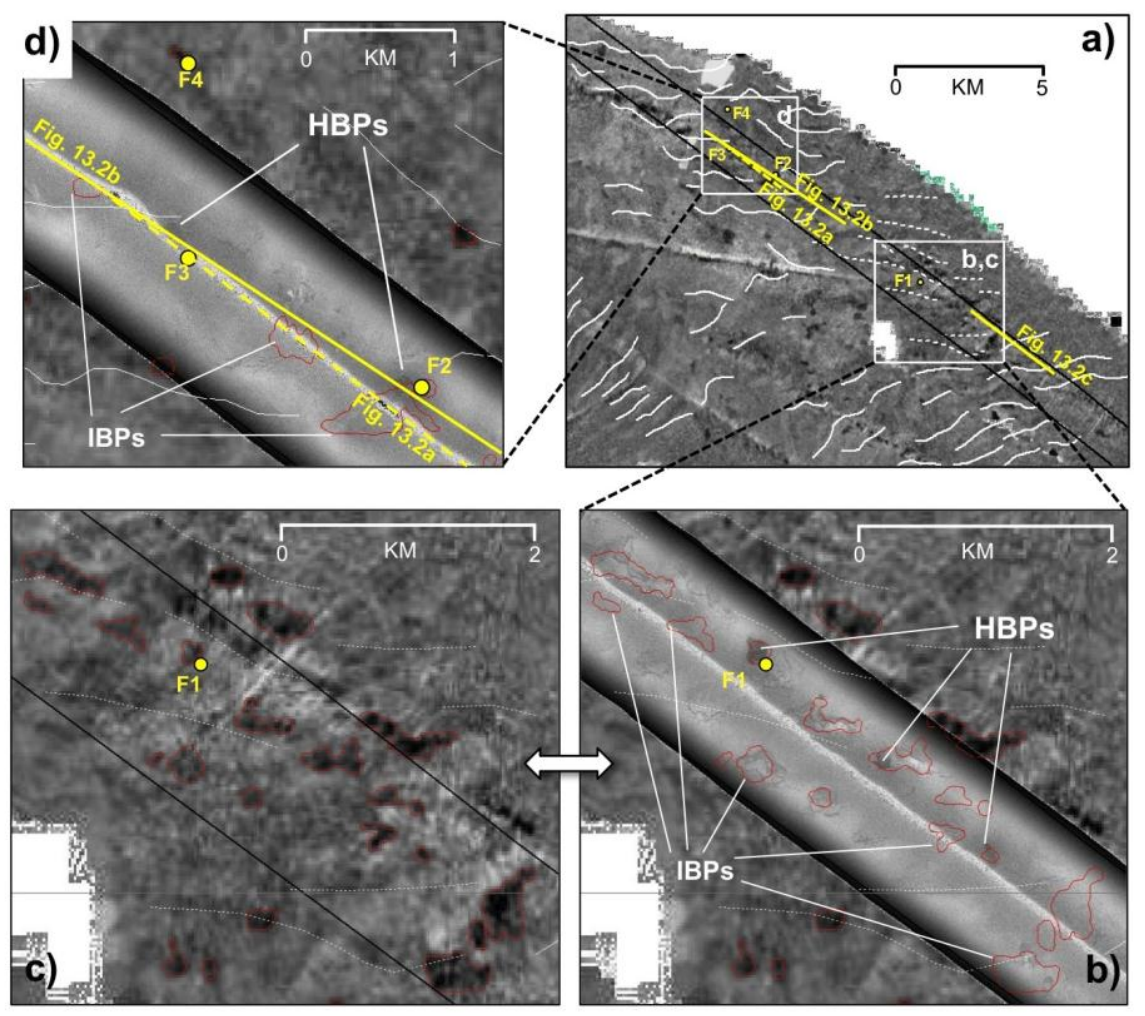


Fig. 13.4 - Visualisation of water column gas flares on multibeam and sidescan imagery relative to seabed HBPs: a) location of flares F1-4 from multibeam water column data, c. $100 \mathrm{~m}$ wide and rising 400-800m above seabed (locations also in Fig. 3a); b,c) flare F1 at the edge of an HBP, $>250 \mathrm{~m}$ from the centre of the c.1100m wide SAR swath; d) flare F2 at the edge of an HBP, $<250 \mathrm{~m}$ from the SAR water column profile which resolves two smaller flares c.60m apart.

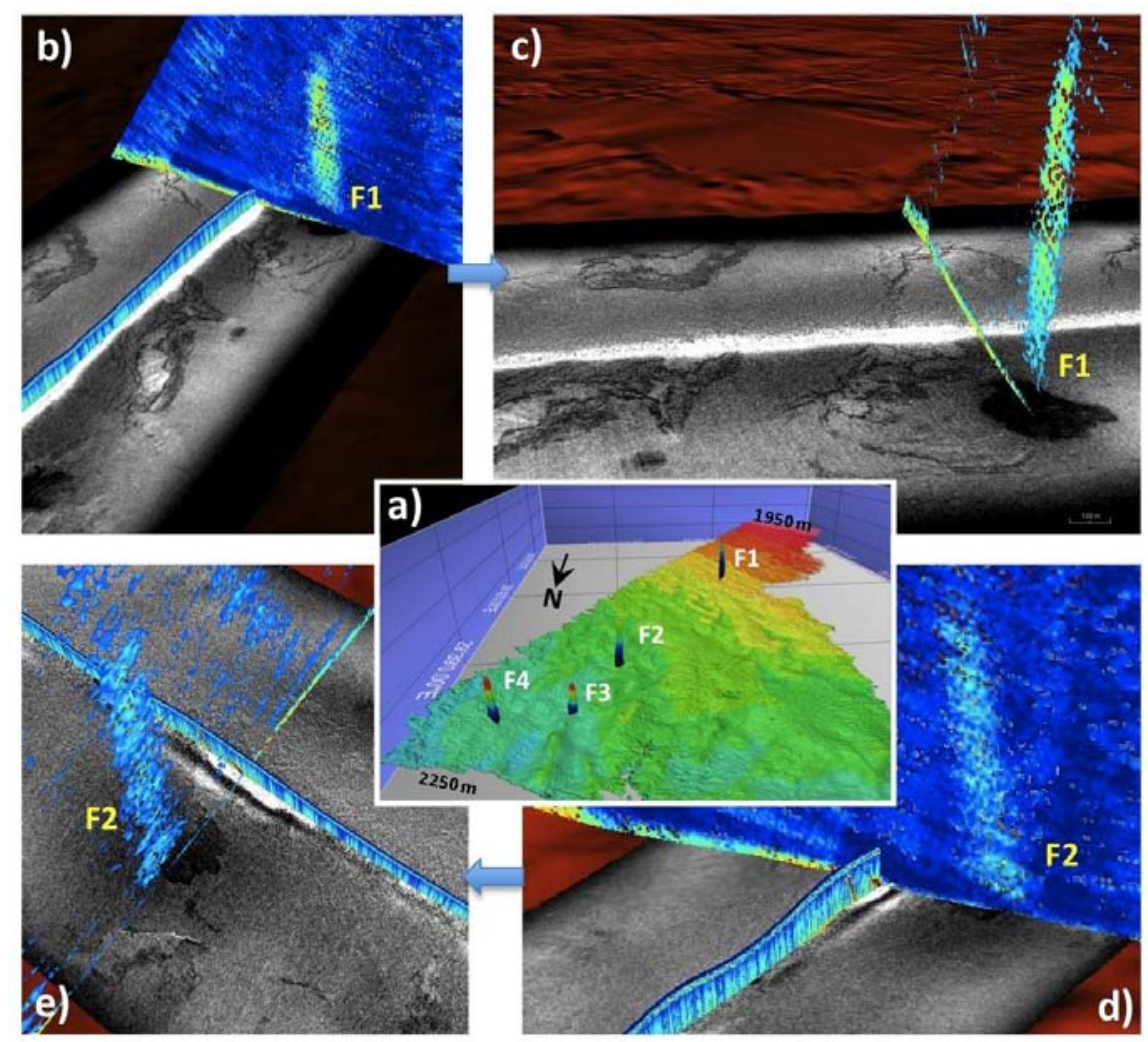

